\title{
Habitat factors influencing the presence of adult Calopteryx splendens (Odonata: Zygoptera)
}

\author{
Louise WARD and PeTER J. MILL* \\ School of Biology, L.C. Miall Building, University of Leeds, Leeds, LS2 9JT, UK; e-mail: p.j.mill@leeds.ac.uk
}

Key words. Range expansion, Calopteryx splendens, riverine, habitat preference, territoriality, habitat availability

\begin{abstract}
In Great Britain the distribution of the riverine damselfly Calopteryx splendens is predominantly southern. However, the last decade has seen records of the species in previously unoccupied areas in the northeast of England, prompting speculation regarding northward range expansion. The current study is the first to quantify the physical features of the habitat that influence the presence of $C$. splendens.

2. A field survey was carried out on the physical characteristics of habitat supporting C. splendens along a section of the River Wharfe, West Yorkshire, U.K. Adult C. splendens were marked uniquely for individual identification in order to assess the occurrence of the species within different habitat patches of the study area.

3. A multiple logistic regression was used to identify the significant habitat variables in explaining the occurrence of adult $C$. splendens.

4. The most important habitat factor in determining the presence of $C$. splendens was the height of the vegetation at the edge of the river. Significant negative relationships were found between the presence of $C$. splendens and tree coverage along the bank, and between its presence and increased bank height.

5. The distribution of C. splendens is affected by the natural physical features of the habitat, anthropogenic disturbance and the behaviour of the species itself.

6. The importance of quantitative habitat data in species conservation, particularly with regard to range expansion, is discusse d.
\end{abstract}

\section{INTRODUCTION}

With the constant threat of species loss due to habitat degradation and destruction, species conservation depends upon knowledge of those factors that sustain the presence of a given species. This information may be of further practical use when considering the possibilities of range expansion.

Animals should respond positively to environments in which their survival and reproductive success are high, and ideally a suitable habitat should contain a mosaic of habitat patches that provide the opportunity for all activities required for successful reproduction (Orians \& Wittenberger, 1991). Habitat selection can be viewed as a hierarchical process whereby an organism initially selects a general place in which to live and then makes subsequent decisions about the use of different patches within that habitat (for Odonata see, e.g., Corbet, 1999). However, the scale on which habitat selection occurs depends upon the size and mobility of a species, and on the spatial structuring of the environment (Jaenike \& Holt, 1991). For many invertebrate taxa, habitat selection has been considered to be a function of oviposition site preference, a factor found to enhance the survival and development of offspring (Jaenike \& Holt, 1991; Atienza et al., 1996; Yáñez \& Floater, 2000).

Attempts have been made to describe aspects of adult habitat selection in various odonate species (Wildermuth, 1993, 1994; Raab et al., 1996). For some, foraging is spatially wide-ranging, whereas activities such as perching and oviposition, particularly in territorial species such as Calopteryx splendens (Harris) (Odonata: Zygoptera: Calopterygidae), are localised and intensive. In most cases, selection of oviposition sites by females and associated perching sites by males are considered to be the main cues in habitat selection, although age-specific habitat selection has been reported in males of C. maculata (Beauvois) (Kirkton \& Schultz, 2001).

In Great Britain, C. splendens is widely distributed in the lowland areas to the south, but is absent from Scotland and, until relatively recently, most of northern England (Merritt et al., 1996). However, in recent years it has been reported from previously unoccupied areas in the far northeast of England (Gibbons \& Moxon, 1998; Jeffries, 2001), prompting speculation regarding its northward expansion in Britain. Adult males are territorial, selecting an area of stream in which successful breeding and oviposition, by the female, can be achieved. The presence of vegetation plays an intrinsic part in territory selection (Raab et al., 1996) as the male selects a vantage point from which to guard his territory and to obtain optimal exposure to sunlight. Eggs are laid endophytically into leaf or stem tissue of aquatic plants and, subsequently, the larvae are generally found amongst the root stems of emergent vegetation (Zahner, 1959; Corbet, 1962). The location of the larvae is controlled, to some extent, by respiratory requirements (Corbet, 1962), which are only met in water with an adequate unidirectional flow. This factor

\footnotetext{
* Corresponding author.
} 
tends to restrict their distribution mainly to streams and rivers.

British riverine odonates are few and have been largely under-studied in comparison to lentic habitat species, which are generally eurytopic. Increasingly, waterways are becoming adversely affected by pollution and flood events, which are detrimental to both fish and invertebrate populations (Nislow et al., 2002). This paper is the first to quantify the physical features of the habitat that influence the presence of adult C. splendens in Britain. Data such as these are useful in the development of conservation strategies for riverine odonates.

\section{MATERIAL AND METHODS}

Between May and September 2000 and 2001 an intensive field survey was carried out along one side of a $1.5 \mathrm{~km}$ stretch of the River Wharfe at Newton Kyme, West Yorkshire, England (53⒌'5'N, $1^{\circ} 16$ '57'W; British National Grid Reference SE470452) to determine those physical aspects that influence the presence of the damselfly Calopteryx splendens. The riverbank vegetation composition varied, with gently sloping banks of dense vegetation, steep-sloped sand banks with little or no vegetation and stretches of bank lined with broad-leaved trees. The opposite bank was not surveyed as it was heavily tree-lined and inaccessible. The study area was divided into 300 continuous sections of $5 \mathrm{~m}$ along the riverbank, which were demarcated using wooden pegs. Physical characteristics of the habitat, which were considered likely to influence the presence of adult C. splendens were recorded. These included depth of water $(\mathrm{m})$ and flow rate $\left(\mathrm{m} \mathrm{s}^{-1}\right)$, both measured at the edge of the bank, where territory selection and ovipositions were observed. Also the angle of the bank slope $\left({ }^{\circ}\right)$ was measured using a clinometer and, subsequently, the height $(\mathrm{m})$ and width $(\mathrm{m})$ of the riverbank were calculated using trigonometry. A metre rule and drop disc were used to measure the height of the bankside annual vegetation $(\mathrm{m})$ at the edge of the water and at one metre from the water's edge. All variables were measured in triplicate within each of the 300 sections (at $1 \mathrm{~m}, 3 \mathrm{~m}$ and $5 \mathrm{~m}$ from the start of each section) and an average value for each habitat variable was calculated over each $5 \mathrm{~m}$ section. Percentage coverage of herbaceous vegetation within each $5 \mathrm{~m}$ section was estimated and the presence or absence of aquatic macrophytes, trees, cattle disturbance and Sand Martin, Riparia riparia (Aves: Hirundinidae), burrows were also recorded. Cattle disturbance was defined by a) direct observation of cattle using specific areas of bank to reach the river for drinking water, and b) evidence of cattle disturbance through trampled and grazed bank side vegetation and hoof prints.

Adult $C$. splendens were observed and captured, using an insect sweep net, over 18 days between $24^{\text {th }}$ June and $21^{\text {st }} \mathrm{July}$, 2000. A total of 724 males and 683 females were captured and marked for the purpose of the study. Each damselfly was given a unique number on the left forewing using a fine indelible pen. This permitted individual identification, thus avoiding multiple recording of the same individual. Upon capture the location of each individual was estimated to the nearest one metre. All animals were released as near as possible to their point of capture. The entire $1.5 \mathrm{~km}$ section of riverbank was surveyed on each sampling occasion. Subsequently, the $C$. splendens count data for the 18 day period were pooled for each $5 \mathrm{~m}$ section from which habitat data were collected, thus providing 300 data points.

\section{Data analysis}

Co-linearity of the independent variables was investigated by production of a correlation matrix. The inclusion of two independent variables with a bivariate correlation of 0.70 or more can have adverse effects on the estimated regression parameters and lead to inflation of the associated confidence intervals (Quinn \& Keough, 2002), thus deletion of one of the two redundant variables is necessary (Tabachnick \& Fidell, 1983). Subsequently, bank width and the angle of slope were removed from the final multiple logistic regression model due to co-linearity with bank height. Similarly, percentage coverage of herbaceous vegetation was removed due to co-linearity with vegetation height at the edge of the river and vegetation height at $1 \mathrm{~m}$ from the water's edge.

A backwards, stepwise logistic regression was used to identify habitat variables explaining the greatest proportion of variation in C. splendens presence/absence data. Of 300 observations, 204 and 96 were presence and absence records, respectively. The first logistic regression model incorporated all habitat variables. Subsequently, the variable that was least significant in accounting for deviance was rejected, and a second model fitted with the remaining variables. This process of elimination was repeated until all remaining variables in the model were significant. All data were analysed using SPSS version 9.0.

\section{RESULTS}

A summary of the habitat variables that were measured and the range and median for each are provided in Table 1. Following stepwise elimination of all insignificant independent variables, three significant variables remained (Table 2). Of these the $\beta$ values show that the vegetation height at the edge of the river explained the greatest proportion of the variation in the presence/absence of adult $C$. splendens $(\mathrm{P}<0.001)$. However, although the bank side vegetation $1 \mathrm{~m}$ from the edge of the river was found not to be significant after step-wise elimination (Table 2), it did show a significant, highly positive correlation with the abundance of $C$. splendens $\left(r_{s}=0.57, P<0.001\right)$, as also did the percentage coverage of herbaceous vegetation on the bank $\left(\mathrm{r}_{\mathrm{s}}=0.55, \mathrm{P}<\right.$ 0.001).

The other two significant relationships resulting from the multiple logistic regression were both negative, i.e. those between $C$. splendens presence and tree coverage along the bank $(\mathrm{P}<0.001)$, and between its presence and the height of the bank $(\mathrm{P}=0.02)$ (Table 2$)$.

The habitat characteristics associated with the aquatic habitat: water depth, flow rate and the presence of aquatic macrophytes, were not significant in describing the occur-

TABLE 1. Summary of the habitat variables measured.

\begin{tabular}{lll}
\hline Habitat variable & Range & Median \\
\hline Water depth $(\mathrm{m})$ & $0.05-1.41$ & 0.41 \\
Flow rate $\left(\mathrm{m} \mathrm{s}^{-1}\right)$ & $0-0.91$ & 0.15 \\
Bank width $(\mathrm{m})$ & $0.44-7.93$ & 2.41 \\
Bank height $(\mathrm{m})$ & $0.09-9.32$ & 1.12 \\
Bank slope $\left({ }^{\circ}\right)$ & $4.67-62.0$ & 26.5 \\
Vegetation height at edge $(\mathrm{m})$ & $0-1.89$ & 0.34 \\
Vegetation height at $1 \mathrm{~m}(\mathrm{~m})$ & $0-1.78$ & 0.20 \\
\hline
\end{tabular}


TABLE 2. Results of the multiple logistic regression showing the effects of habitat variables on the presence or absence of adult $C$. splendens.

\begin{tabular}{|c|c|c|c|c|}
\hline \multirow[b]{2}{*}{ Habitat variable } & \multicolumn{4}{|c|}{ Multiple logistic regression } \\
\hline & $\beta$ & Wald & d.f. & $\mathrm{P}$ \\
\hline Water depth & 0.12 & 0.03 & 1 & N.S. \\
\hline Flow rate & 5.98 & 1.23 & 1 & N.S. \\
\hline Bank height & -0.28 & 5.39 & 1 & 0.02 \\
\hline Vegetation height (at edge) & 4.90 & 53.02 & 1 & $<0.001$ \\
\hline Vegetation height (at $1 \mathrm{~m}$ ) & 0.97 & 0.48 & 1 & N.S. \\
\hline Tree presence & -0.34 & 14.35 & 1 & $<0.001$ \\
\hline Aquatic macrophytes & 0.09 & 0.45 & 1 & N.S. \\
\hline Cattle disturbance & -0.06 & 0.31 & 1 & N.S. \\
\hline Riparia riparia burrows & -0.11 & 1.53 & 1 & N.S. \\
\hline
\end{tabular}

$\beta$ is the estimate of change in the dependent variable that is attributed to a one unit change in the independent variable.

The Wald statistic is approximately equal to the G-test (Sokal \& Rohlf, 1995).

The multiple logistic regression shows the three significant habitat variables remaining after stepwise elimination of the insignificant variables.

N.S. = not significant.

rence of $C$. splendens; nor were the presence of $R$. riparia burrows and cattle disturbance (Table 2). However, albeit weak, a significant negative correlation was found between the number of adult $C$. splendens and the occurrence of cattle disturbance $\left(\mathrm{r}_{\mathrm{s}}=-0.31, \mathrm{P}<0.001\right)$.

\section{DISCUSSION}

Results of the current study found that the vegetation height at the edge of the river was the most important habitat factor for the occurrence of adult C. splendens. Tall stands of the dominant riparian species, Phalaris arundinacea (Canary Reed-grass), were used as vantage points for territory-holding males (pers. obs.). These male perching sites are selected in the region of attractive oviposition sites (Corbet, 1962; Gibbons \& Pain, 1992) and as optimum vantage points from which to guard and defend the territory from conspecific males. Indeed, habitat selection based on oviposition site is practised by species for which the oviposition site forms the basis for territorial activity (Corbet, 1999). For species that oviposit endophytically, such as $C$. splendens, vegetation is not only important as an oviposition substrate, but also as refugia for the developing larvae. Thus the larvae of this species, for example, inhabit the silty areas amongst the stems and roots of riparian vegetation (Brooks, 1997). For most odonate species, vegetation plays a pivotal role in all life stages - as perching (Raab et al., 1996) and oviposition sites for adult males and females, respectively, and as a support for emerging larvae. As such, it is likely a priori that riverside macrophytes feature prominently among cues for habitat selection (Corbet, 1999), although the structure of plant communities is probably more important than individual plant species (Corbet, 1999). The results suggest that a dense covering of herbaceous bank side vegetation is preferable. Adult $C$. splendens shelter amongst the stems and foliage of bank side vegetation during periods of adverse weather, such as high winds and rainfall (pers. obs.). Indeed, Jeffries (2001) noted the importance of dense riparian vegetation, including grasses and herbs, in areas supporting C. splendens.

Logistic regression showed that cattle disturbance was not independently related to the presence of C. splendens, although the two were negatively correlated, albeit weakly. Regular disturbance by cattle along specific sections of the riverbank caused an increase in bare ground where vegetation had been trampled and a reduction in vegetation height through grazing (pers. obs.). Considering the importance of tall, dense stands of bank side vegetation for the presence of $C$. splendens, cattle disturbance is a factor that has an adverse effect upon the presence of the species. Harrison \& Harris (2002) found that Calopterygidae were significantly associated with ungrazed margins. Indeed, they observed large numbers of adult $C$. splendens resting, feeding and mating among the tall herbaceous vegetation in ungrazed bankside stretches. Heavily grazed and denuded bank sides are thus unsuitable for C. splendens.

In contrast to the importance of bank side vegetation for the presence of $C$. splendens, tree coverage along the bank had a negative effect. In addition to the possible effect of tree shade on herbaceous growth, the reduction in exposure to sunlight immediately beneath and to the adjacent areas lowers the ambient temperature. The heat provided by direct exposure to the sun is imperative in maintaining activity in poikilotherms. Trees are also unsuitable as perching and oviposition substrata.

The height of the riverbank was negatively associated with the presence of $C$. splendens. This relationship is probably not causative, but is likely a proxy for some unmeasured variable. The burrows of $R$. riparia were frequently located in high, steep banks and it was considered, a priori, that $C$. splendens adults would not be present in conjunction with $R$. riparia as the latter had been observed predating upon the former. However, being highly mobile, $R$. riparia were not restricted to the immediate area of their burrows and were observed predating upon $C$. splendens on the wing. Also, discarded $C$. 
splendens wings were found below a number of the $R$. riparia burrows.

Gibbons \& Pain (1992) found that river flow rate influenced the presence of adult Calopteryx. Females of $C$. splendens xanthostoma and $C$. haemorrhoidalis preferred to oviposit in aquatic vegetation found in fast flowing water up to $0.6 \mathrm{~m} \mathrm{~s}^{-1}$. Thus territorial disputes between males of both species were more common in fast flowing parts of streams, leaving the slow flowing areas often undefended. In addition, the mating success of C. s. xanthostoma increased with the rate of flow of water through their territory. However, in the current study, flow rate was not found to be a significant habitat factor influencing the presence of $C$. splendens, although the maximum flow rate in the study area was $0.91 \mathrm{~m} \mathrm{~s}^{-1}$.

The physical attributes of a species' habitat that can be studied are restricted to those that can be categorised by the human observer (Corbet, 1999; Cowley et al., 2000). For Odonata, interpreting the habitat characteristics that are selected by individuals in a population can be difficult, as consideration of the requirements of both life stages, aquatic larva and terrestrial adult, is necessary. Although the habitat requirements of many species are largely based on easily measured habitat features, such as landscape patterns and vegetation physiognomy (Storch \& Frynta, 1999), other factors, such as intraspecific population pressure, may result in utilisation of a greater variety of habitats (Rosenzweig, 1991). A decline in habitat selectivity with increased population density has been reported for many taxa (e.g. Morisita, 1952; Pimm et al., 1985). However, an increase in population density has been shown to reduce the number of territory-holding males, rather than increase spatial dispersion rates, in both C. splendens (Zahner, 1960) and C. maculata (Waage, 1972). Zahner (1960) reported non-territorial $C$. splendens at densities of between 30 and 60 males per 10 $\mathrm{m}$ of bank. In the present study, the highest male density recorded in any one area was 35 per 10 m of riverbank.

Like many adult odonates, $C$. splendens has a prerequisite for tall herbaceous bankside vegetation in which to carry out the activities culminating in successful reproduction. Thus intensive bankside management practices that result in the denudation of bankside vegetation (for example, mowing or strimming to improve public access or for agricultural purposes) are not conducive to supporting $C$. splendens populations. In addition, the presence of plentiful shrubs and trees provides unsuitable perching and oviposition substrata and hence is also unfavourable habitat.

Recent records of $C$. splendens in England have led to speculation that the species is increasing its range northwards on the east side of the country (Ward \& Mill, 2004), with the most northerly records to date on the rivers Wansbeck and Blyth in southern Northumberland (Jeffries, 2001). A potential barrier to further northward movement could be the topography of the riverine habitat in the north of England and in Scotland. A large proportion of the latter is mountainous with rapidly flowing, turbulent rivers that flow over pebble and boulder substrata.
Conditions such as these tend to restrict the establishment of in-stream vegetation. This is in contrast to the meandering, lowland English rivers with silt substrata and well established in-stream vegetation growth, which are inhabited by $C$. splendens populations. It would be beneficial to conduct studies, similar to the current one, at the most northerly extent of $C$. splendens' range to assess whether the important physical habitat features there are comparable to those in the core of its range.

For highly mobile animals, such as birds and some insects, redistribution of individuals among the remaining habitats may occur as the availability of habitat is altered (Pulliam \& Danielson, 1991). Where a species occurs in several distinct habitat types, in the same local region, it may experience different development rates, survival rates and reproductive success in the different habitats (Pulliam \& Danielson, 1991; see e.g. Grant, 1975). This could be crucial for a species at the edge of its range where successful range expansion is dependent upon the availability of sufficient suitable habitat.

ACKNOWLEDGEMENTS. The authors thank A. Ward (Central Science Laboratory) for helpful comments on an earlier version of the manuscript. The research was supported by the John Henry Garner Scholarship, University of Leeds.

\section{REFERENCES}

Atienza J.C., Farinós G.P. \& Zaballos J.P. 1996: The role of temperature in habitat selection and activity patterns in the ground beetle Angoleus nitidus. Pedobiologia 40: 240-250.

Brooks S. 1997: Field Guide to the Dragonflies and Damselflies of Great Britain and Ireland. British Wildlife Publishing, Hampshire, UK, 160 pp.

CORBET P.S. 1962: A Biology of Dragonflies. Witherby, London, $247 \mathrm{pp}$.

Corbet P.S. 1999: Dragonflies - Behaviour and Ecology of Odonata. Harley Books, Essex, UK, 829 pp..

Cowley M.J.R., Wilson R.J., LeON-Cortes J.L., Gutierrez D, Bulman C.R. \& Thomas C.D. 2000: Habitat-based statistical models for predicting the spatial distribution of butterflies and day-flying moths in a fragmented landscape. J. Appl. Ecol. 37: $60-72$.

Gibions D.W. \& Moxon J.B. 1998: Calopteryx splendens (Harris) at edge of range sites in North-East England. J. Br. Dragonfly Soc. 14: 33-44.

Gibbons D.W. \& Pain D. 1992: The influence of river flow rate on the breeding behaviour of Calopteryx damselflies. J. Anim. Ecol. 61: 283-289.

GRANT P.R. 1975: Population performance of Microtus pennsylvanicus confined to woodland habitat, and a model of habitat occupancy. Can. J. Zool. 53: 1447-1465.

HARrison S.C. \& Harris I.T. 2002: The effects of bankside management on chalk stream invertebrate communities. Freshwat. Biol. 47: 2233-2245.

JAENIKE J. \& Holt R.D. 1991: Genetic variation for habitat preference: Evidence and explanations. Am. Nat. (Suppl.) 137: $67-90$.

JefFries M. 2001: The Northumbrian frontier of the Banded Demoiselle Calopteryx splendens (Harris). J. Br. Dragonfly Soc. 17: 55-58.

KiRKTON S.D. \& Schultz T.D. 2001: Age-specific behaviour and habitat selection of adult male damselflies, Calopteryx maculata (Odonata: Calopterygidae). J. Insect Behav. 14: 545-556. 
Merritt R., Moore N.W. \& Eversham B.C. 1996: Atlas of the Dragonflies of Britain and Ireland. ITE Research Publications no. 9, HMSO, Great Britain, 151 pp.

Morisita M. 1952: Habitat preference and evaluation of environment of an animal: experimental studies on the population density of an ant lion, Glenuroides japonicus. Physiol. Ecol. 5: $1-16$.

Nislow K.H., Magilligan F.J., Folt C.L. \& Kennedy B.P. 2002: Within-basin variation in the short-term effects of a major flood on stream fishes and invertebrates. J. Freshwat. Ecol. 17: $305-318$.

ORIANS G.H. \& WitTENBERGER J.F. 1991: Spatial and temporal scales in habitat selection. Am. Nat. (Suppl.) 137: 29-49.

Pimm S.L., Rosenzweig M.L. \& Mitchell W. 1985: Competition and food selection: field tests of a theory. Ecology 66 798-807.

Pulliam R.H. \& Danielson B.J. 1991: Sources, sinks and habitat selection: A landscape perspective on population dynamics. Am. Nat. (Suppl.) 137: 50-66.

QuinN G.P. \& KeOugh M.J. 2002: Experimental Design and Data Analysis for Biologists. Cambridge University Press, Cambridge, $556 \mathrm{pp}$.

RaAb R., Chovanec A. \& Wiener A.K. 1996: Aspects of habitat selection by adult dragonflies at a newly created pond in Vienna, Austria. Odonatologica 25: 387-390.

RozenZweig M.L. 1991: Habitat selection and population interactions: the search for mechanism. Am. Nat. (Suppl.) 137: $5-28$.

Sokal R.R. \& Rohlf F.J. 1995: Biometry. 3rd ed. W.H. Freeman, New York, 887 pp.
Storch D. \& Frynta D. 1999: Evolution of habitat selection: stochastic acquisition of cognitive clues? Evol. Ecol. 13: 591-600.

TABACHNICK B.G. \& FidELL L.S. 1983: Using Multivariate Statistics. Harper \& Row, New York, 932 pp..

WAAGE J.K. 1972: Longevity and mobility of Calopteryx maculata (Beauvois, 1805) (Zygoptera: Calopterygidae). Odonatologica 1: 155-162.

Ward L. \& Mill P.J. 2004: Distribution of Calopteryx splendens (Harris) in northern England: an example of range expansion? J. Br. Dragonfly Soc. 20: 61-69

WILDERMUTH H. 1993: Habitat selection and oviposition site recognition by the dragonfly Aeshna juncea (L.): an experimental approach in natural habitats (Anisoptera: Aeshnidae). Odonatologica 22: 27-44.

Wildermuth H. 1994: Habitatselektion bei Libellen. Odonatologica 6: 223-257.

YÁÑEZ M. \& FloAter G. 2000: Spatial distribution and habitat preference of the endangered tarantula, Brachypelma klaasi (Aranae: Theraphosidae) in Mexico. Biodiv. Conserv. 9: 795-810.

ZAHNER R. 1959: Über die Bindung der mitteleuropäischen Calopteryx-arten (Odonata, Zygoptera) an den Lebensraum des strömenden Wassers. I. Der Anteil der Larven an der Biotopbindung. Int. Rev. Gesam. Hydrobiol. Hydrogr. 44: 51-130.

ZAHNER R. 1960: Über die Bindung der mitteleuropäischen Calopteryx-arten (Odonata, Zygoptera) an den Lebensraum des strömenden Wassers. II. Der Anteil der Imagines an der Biotopbindung. Int. Rev. Gesam. Hydrobiol. Hydrogr. 45: 101-123.

Received May 3, 2004; revised August 7, 2004; accepted August 9, 2004 
